\title{
Working Remotely During the COVID-19 Pandemic: Efforts of the Ministry of Education in the United Arab Emirates
}

\author{
Rawadha AlMarar $^{\text {a }}$ iD, Amani Alkhodari a 1 iD, Dina Y. Atia a iD \\ Satti Mohamed a $^{\text {iD }}$ Raed M Shubair a iD \\ ${ }^{a}$ Ministry of Education, Abu Dhabi, United Arab Emirates
}

\begin{abstract}
APA Citation:
AlMarar, R., Alkhodari, A., Atia, D.Y., Mohamed, S. \& Shubair, R. M. (2021). Working remotely during the covid-19 pandemic: efforts of the ministry of education in the United Arab Emirates. TIJAB (The International Journal of Applied Business), 5(1), 01-17.

Submission Date: 01/11/2020

Acceptance Date: 21/03/2021
\end{abstract}

\begin{abstract}
Following the global outbreak of COVID-19 pandemic, work is no longer being conducted in the traditional manner. This has created pressure on businesses to shift into a mode of remote working in order to avoid severe disruption. The United Arab Emirates (UAE) has attempted to face challenges accompanying this crisis and explore solutions with the wise vision and constant support of its leadership. This paper examines the transition of working procedures at one of the most influential entities in the UAE; the Ministry of Education (MOE). The purpose here is to shed light on how obstacles have been turned into opportunities in order for MOE employees to continue working remotely during such critical conditions. This is illustrated by the efforts of ministry departments that were interviewed for their feedback during the study. This paper provides insights into the activation of remote work in response to sudden incidents by highlighting measurements and factors that contribute to entities' readiness for such a transition. This study analyzes the value and originality of MOE remote working practices and their impact on the wider community.
\end{abstract}

Keywords: working remotely; telework; remote work; virtual environments; COVID19

This is an open access article under the CC BY-NC-SA license.

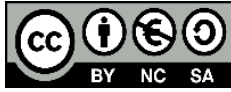

\section{Introduction}

In a world where Information and Communication Technologies (ICT) advance constantly in order to address the needs of an increasingly fast-paced life, it is no surprise that concepts of where and how work is performed are altering accordingly. An increasing reliance on information technology infrastructures has rendered jobs more dynamic and has shifted businesses mindsets into alternative workplace environments, namely working remotely. Various definitions have been adopted to describe

\footnotetext{
${ }^{1}$ Corresponding author.

E-mail address: amani.alkhodari@moe.gov.ae
} 
remote working as in (Elshaiekh, Hassan, \& Abdallah, 2018), (Clark, 1998), and (OLSON, 1983). All of these, however, revolve around the same basic concept of completing tasks away from a physical office space with increased flexibility in time and schedule planning. This concept of virtual working environments and virtual teams is actually not new to countries and industries worldwide. Since the early 1980s, the availability of the Internet and Wi-Fi-based tools has been allowing workers to communicate over long distances, saving time and cost. With the advancement in laptops and smart phones since the beginning of the 21 st century, telework has been gaining more attention and popularity both industrially and in literature as will be discussed later in this paper. In early 2020, when the World Health Organization (WHO) declared the COVID-19 outbreak a pandemic in early 2020, this caused huge impact on lives and communities (World Health Organization, 2020). Consequently, businesses and organizations all over the globe have shifted their working style into virtual environments by having their employees work remotely.

In the United Arab Emirates (UAE), the shift from the conventional physical workplace into virtual working environments was gradual and planned, placing a priority on the health and well-being of citizens. A remote work system was initially launched in the public sector for employees vulnerable to COVID-19 infection; mothers, pregnant women, elderly people, people of determination, and those with health issues that may compromise their immune system (Federal Authority For Government Human Recources, 2020). The system was then expanded to include almost all other employees in the public sector such as ministries, authorities, and federal institutions. Regulatory guidelines were simultaneously presented for companies in the private sector. A maximum of $30 \%$ of the workforce of each entity concerned was permitted to be physically present in any workplace whilst maintaining hygiene and physical distancing. Other employees whose work did not require them to be physically present in the office were obliged to work from home. Similar precautions in private establishments were likewise emphasized (United Arab Emirates Ministry of Human Resources and Emiratisation, 2020). Alongside this, a daily sterilization program with extensive disinfection procedures was implemented subject to review and renewal (United Arab Emirates Ministry of Interior, 2020 ).

Highlighting the importance of the education sector during the time of the pandemic, the UAE aimed to ensure the continuation of education for all students in schools and higher education institutions through e-learning from home, with the majority of teachers and education professionals working remotely. The UAE aimed to utilize its well-developed Information and Communications Technology (ICT) systems to make this shift to a process of e-learning and remote working be as seamless and smooth as possible.

Prior to the declaration of COVID-19 as a pandemic, the Ministry of Education had taken gradual and sequential steps to respond to these critical conditions through policies and decisions aiming to ensure the safety of employees and students in the UAE. Figure 1 shows the timeline of the ministry transitioning into remote working from the period of February - April 2020 during which this study was conducted.

To smoothly progress into e-learning/remote working environment, the Ministry of Education has initiated a list of procedures and decisions. The ministry applied those procedures on three target groups which are General Education (Nurseries and Schools), Higher Education (Colleges and Universities), and within the Ministry of Education departments.

In General Education, the ministry suspended nurseries and schools by bringing forward the spring break to allow intensifying sterilization of schools and busses, to start health and safety awareness campaigns for teachers, parents, and children, as well as to transfer education to online platforms and set guidelines for implementation. It also started an initiative to support low-income families through providing laptops/tablets to ensure all students had accessibility. 
In Higher Education, a virtual meeting was held with higher education universities and colleges to highlight any possible challenges for online education transfer, creating a poll to see which institutes were ready for an immediate switch to online education and which institutes required support in the transfer. For those requiring support, spring break would also be brought forward to facilitate the change. Upon the transfer, institutes had to go through an evaluation by the ministry as well as student surveys conducted also by the ministry to ensure that services meet the standards. Once education turned to online, all campuses and dorms had to go through intensified sterilization.

Finally, within the ministry itself, the transition was gradual to working by distance, starting with $25 \%$ of employees, and continuing up to $100 \%$. The $25 \%$ precent first included pregnant women and mothers of children, the elderly, people with disabilities "people of determination" and those with health issues. For employees in the workplace before reaching the $100 \%$ of working by distance, an ABC work model (which will be discussed further in the coming sections) was implemented during the transitional period to strictly limit physical interaction between employees. The ministry also issued across all its sectors a circulation of travel declaration to all teachers and students including their family members, imposing quarantine when necessary.

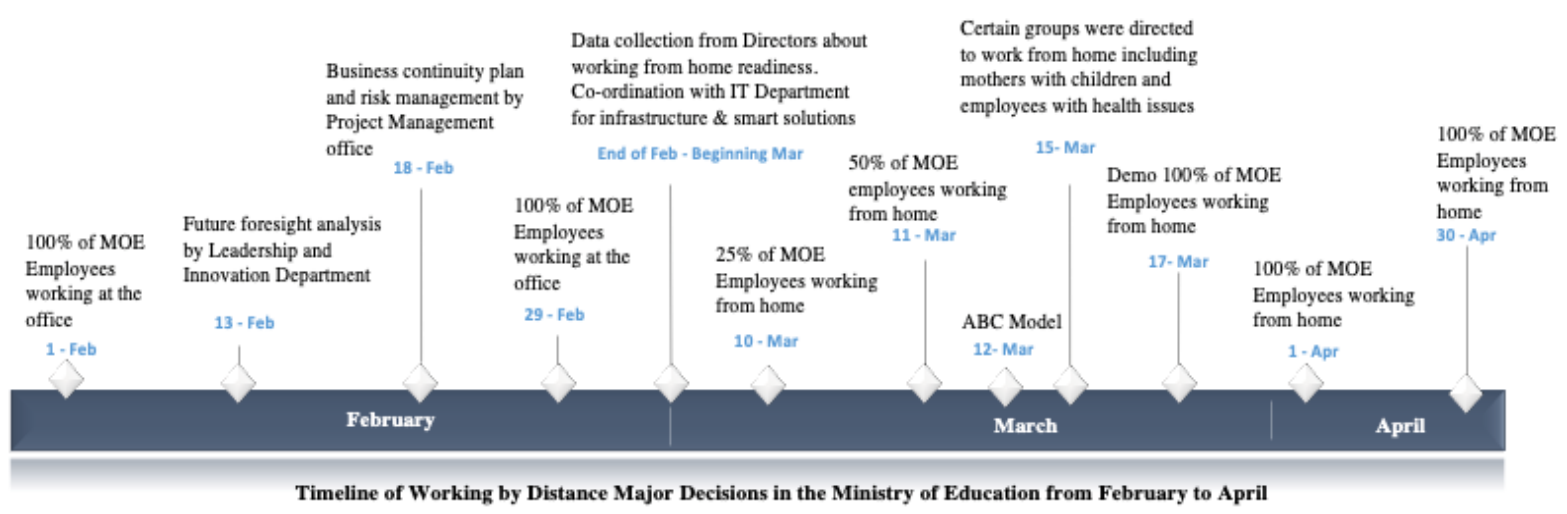

Figure 1: MOE timeline for remote working decisions

This paper highlights the MOE transition to remote working and its attempts to maintain the delivery of all services through virtual environments built on reliable ICT platforms. It describes the virtual model adopted and the factors which contributed to the smooth flow and success of the remote working initiative at the MOE. An analysis of departmental readiness is presented in order to demonstrate the contribution of different factors into this transitional process. The paper also discusses how MOE endeavored to develop opportunities for long-term learning and progression out of the various challenges and obstacles these events presented.

\section{Literature Review}

\subsection{Working Remotely: Previous Models and Lessons Learned}

This section briefly reviews the literature surrounding the topic of remote working. It is divided into two parts: the role of ICT in the remote working process, and leadership in virtual environments. Throughout this section, the aim is to identify actionable future initiatives aimed at adding value across this field.

A gradual trend of surveys and research case studies from the 1980s onwards has shown the direction of maturity in telework research (Bailey \& Kurland, 2002). The evolutionary trends of remote working are seen to be following those of the development and enhancement of ICT infrastructures, particularly 
now that most homes are equipped with various forms of technology (Boulin, 2016). There has been an increasing tendency among workers to make use of technology in detaching work from its physical place (Felstead \& Henseke, 2018). A European research project, FLEXCOT, addressed these flexible work practices and communication technologies and posited an interaction between technological innovations and organizational changes (Valenduc \& Vendramin, n.d.). According to the FLEXCOT project, the diversification of flexible work forms is linked to the diffusion of new ICT applications and services. The study did not only consider the location of work but also the issues of variable working times, contracts, and subordination links - contributing elements which are integral in linking the role of ICT to supporting each dimension.

Although much of the literature on telecommuting assumes that technology facilitates the process of working remotely, many still highlight some potential drawbacks. According to (Baker, Avery, \& Crawford, 2006), technology may be detrimental to the development of Home-Based Telecommuting (HBT) when it plays contradictory roles in organizational change. One pattern identified is when contradictory consequences result from the same technology within a single organization; another is when different organizational consequences result from the implementation of the same technology in comparable settings. Besides, technology may impose a threat to employees if downsizing occurs especially in lower and middle level jobs (Kumar, 2014). In fact, views on working remotely concern not only technology but also social and emotional aspects (Iscan \& Naktiyok, 2005) as well as concepts involving shifting work ideas from a physical location to a state of mind (Pierce \& Amant, 2011). It appears true that technology makes working from home more approachable, yet it can be seen as having both positive and negative effects, particularly when any viewpoint involves and affects workers directly.

The literature does not only document the role of ICT in facilitating remote work but also considers the contribution of employers and business leadership. According to a report by the RAND Corporation - an American nonprofit research and development corporation dedicated to global policy analysis for better decision making - on understanding government telework, federal government leaderships are recommended to follow certain procedures when implementing a remote working model. Firstly, clear goals of telework must be stablished and communicated to the workforce. Eligible job positions for the relevant remote practice should then be examined. Policies documenting the entity's implementation of telework should be created, as well as performance measures for the entity as a whole and for the employees involved in the said telework (Weinbaum, Triezenberg, Mezo, \& Luckey, 2018). A European study suggested the consideration of competitiveness measures such as performance, turnover, and absenteeism when establishing a remote work model (Wiley Online Library, 2005). Besides, an employment strategy for specific evaluation of staff possessing the flexibility and skills to work remotely could be advantageous (Oliver, Schoewe, \& Lawrence, 2016). In many cases, it may be advisable for leaders to become engaged and involved in different local and international environments that expose them to alternative perspectives and practices.

Leadership in virtual environments can be challenging to some extent. The lack of interaction that is normally obtained via in-person communication may affect multiple aspects such as workload, response time, emotions, and team collaboration (Bishop, Riopelle, Gluesing, Danowski, \& Eaton, 2010). Leaders in many cases may be held responsible by team members when technological tools are not available to enhance their performance remotely. They can also face the challenge of controlling and monitoring individual team member activity when working remotely and avoiding procrastination by employees due to self-regulation failure and spending time on non-work activities at home as reported by (Wang, Liu, Quan, \& Parker, 2021). Delegation of certain tasks by shifting managerial functions down the hierarchy has therefore been considered (Mehtab, Rehman, Ishfaq, \& Jamil, 2017). It is clearly important for leaders to understand the role of trust during remote work and recognize the factors that contribute 
to it when virtual task delegation occurs (Dangmei, 2016) (Lukić \& Vračar, 2018). The preparation, willingness, and motivation of employees and team members to accept and fulfill such delegated managerial functions is an interesting topic which may not as yet have been fully and adequately explored. According to a recent study, Leaders are recommended to follow a hybrid behavior among their employees that balances between Managing Leadership Behavior (MLB) and Enabling Leadership Behavior (ELB) during times of crises-induced digital transformations (Bartsch, Weber, Buttgen, \& Huber, 2020). MLB supports more task-oriented managing behavior by letting the leaders set clear tasks and provide guidance to their employees, as they best know the goals, resources, and skills of the entire team (Liao, 2017). On the other hand, leaders should apply ELB concept by granting their employees the autonomy allowing them to adapt in a way that best works for them in terms of taking decisions on how and when to do the work and how to handle difficult situations on their own (Mertens \& Recker, 2020).

It should be noted at this stage that the Ministry of Education study in this paper follows the approach of data collection through interviews and measurements accompanied by qualitative analysis, as will be illustrated below.

\subsection{UAE Ministry of Education Virtual Work Model}

The UAE Ministry of Education is one of the largest entities in the country to adopt remote working for employees through virtual environments as a response to the COVID-19 pandemic. The ministry consists of 56 departments that are led by a Minister of Education appointed by the leadership of the country. The whole organizational hierarchy operates under the direction of the Minister with the assistance of a Minister of State for General Education Affairs and a Minister of State for Higher Education Affairs. For each sector in the hierarchy, there is an office led by the Undersecretary and Assistant Undersecretaries for that sector (Ministry of Education in the United Arab Emirates, n.d.). Each sector has several departments handling specialized duties. All ministry departments in all sectors have adopted remote working practices. The adoption process was headed by the ministers with the support of the Strategy and Future department that has a wide experience in crisis management. One of their techniques in dealing with the pandemic was the activation of the $\mathrm{ABC}$ work model that will be explained in detail in the coming sections. They also base their decision on the principle of collaborating with other entities in the country that have a record of taking crucial decisions during hard times. These include the Ministry of Health and Prevention (MOHAP) and the National Crisis and Emergency Management Authority (NCEMA). This study focuses on representative departments including: Information Technology, Strategy and Future, Training and Career Development, Scholarships, Organizational Directorate and Educational International Relations, and Institutional Licensing.

\subsection{Establishment of a Basis: A Reliable Information Technology Infrastructure}

To facilitate the implementation of decisions relevant to e-learning/remote working initiatives, the government of the United Arab Emirates has been keen to further enhance the ICT sector. In coordination with UAE telecom operators (Etisalat, $\mathrm{Du}$ ), the Telecommunications Regulatory Authority (TRA) has launched a number of initiatives since the beginning of the pandemic, including enablement of UAE government entities to work from home and free access to a set of supporting applications. A full list of TRA initiatives can be viewed in (United Arab Emirates Telecommunication Regulatory Authority, n.d.).

Figure 2 below illustrates the virtual model adopted by the Ministry of Education during the remote working period. The model shows how interaction with clients has been maintained through customer 
happiness centers using reliable ICT platforms. The work model proposed at the MOE, the 'ABC work model', is also shown, and will be explained further in the following section.

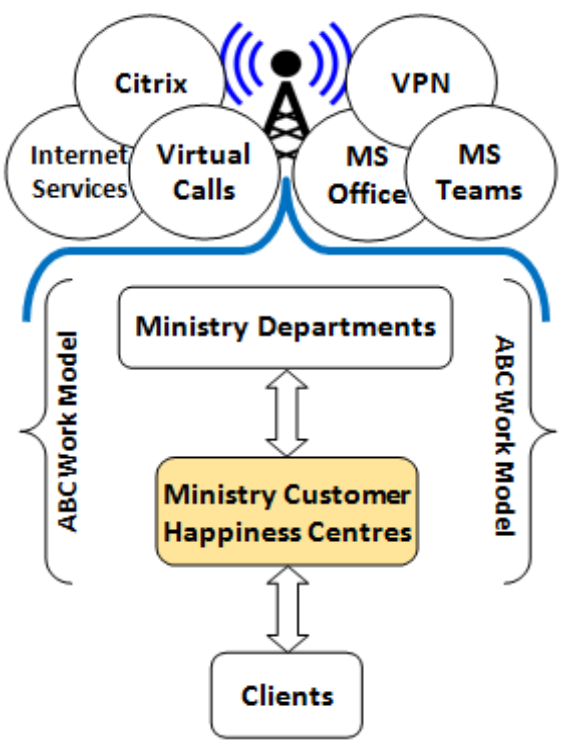

Figure 2: MOE virtual model

\subsection{Activation of the ABC Work Model for Employees}

One of the key decisions of the ministry in collaboration with the National Crisis and Emergency Management Authority (NCEMA) was to divide employees of each department into sub-groups according to an $\mathrm{ABC}$ model. This model divides employees into sub-groups $\mathrm{A}, \mathrm{B}$, and $\mathrm{C}$, and ensures sub-groups do not physically interact in the same location if work should need for any reason to be performed in an office environment during this period (Figure 3). If sub-group A was for a particular reason required to work from the office, then sub-groups B and C would remain working remotely, which would effectively ensure physical distancing.

Sub-groups are also divided according to the nature of individual jobs such that employees working in similar fields or areas are separated to ensure divergence of roles and abilities amongst each subgroup. Logically this is intended to manage the risk of an employee in any specific sub-group suffering from a health issue, which in a worst-case scenario could lead to others in his group becoming infected and the whole group facing the risk of becoming dysfunctional. In such a situation, the job roles of this specific sub-group could still be performed as employees in the remaining sub-groups would be capable of handling similar tasks. Figure 3 below indicates this precautionary convergence. 


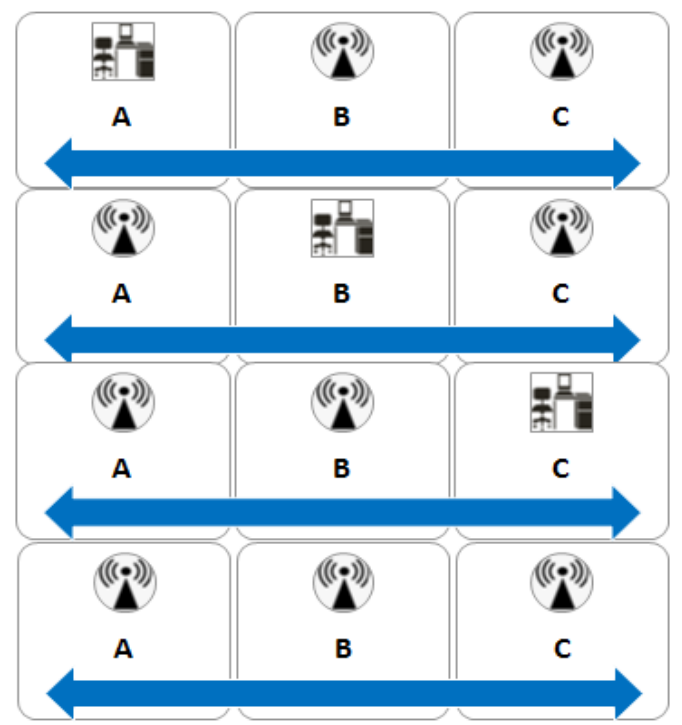

Figure 3: $\mathrm{ABC}$ work model

\subsection{Support from UAE and MOE Leadership}

The UAE 'Vision 2021', established in 2010, envisages nationals and residents in the UAE as 'United in Prosperity, United in Knowledge, United in Destiny, and United in Responsibility' (United Arab Emirates Vision 2021, n.d.). Since the beginning of the COVID-19 pandemic, UAE leadership have thus endeavored to empower and entrust employees across all industries, and to ensure doors for effective communication were always open. In the Ministry of Education, ministers have focused on responding directly to any concerns as well as providing clear guidance to all departments. During the transition period to remote working, all leadership personnel across the ministry have been directed to raise any challenges their teams might face, with the aim of resolving any issues within a period of three weeks.

\section{Method}

\subsection{A Study of the Ministry Departments Readiness for Remote Work}

Quantitative data necessary for this analysis was gathered from interviews with representative departmental and higher management personnel. Interviews were arranged by sending out official emails to the candidate informants and scheduling dates and times suitable for everyone involved. Interviews were conducted virtually using MS Teams by a panel of interviewers consisting of the authors of this paper. Recordings and note taking during each interview discussion were the basis of data collection in this study. Besides, informants were also willing to share some documented data through email after the interview, which aided our research study. This section and the following one examine the MOE's readiness factor, which aims to measure the preparedness of the ministry for the shift to working remotely by evaluating the readiness of its various sectors and departments. It also considers the steps and measurements taken from specific departments as they were sought to adapt to the remote working experience, and how these were reflected in productivity and overall performance.

Upon the emergence of the COVID-19 pandemic, the ministry immediately formed an ad hoc team to address the crisis and report directly to the minister. This team belongs to the Project Management Office of the Strategy and Future department, who have undertaken the initiative of establishing a business continuity project across the ministry. This project supports business continuity 
through: checking the needs of each sector and its departments in terms of availability and needs, assessing the readiness of operations for remote working, calculating the proportion of employees able to work remotely, and finally obtaining overall readiness percentages across MOE sectors, including service departments which typically require in-person interactions with clients.

\section{Results and Discussion}

The study indicates that $75 \%$ of MOE departments were ready to work remotely at the beginning of the crisis while $25 \%$ required support for the transition. Based on this measurement, the business continuity team checked for and determined the common needs between these departments in order to raise the level of their readiness to work remotely. The two most common requirements were: access to systems/documents from home (31\% of overall requirements), and lack of of reliable laptops ( $25 \%$ of requirements). The remaining 44\% of requirements included SIM cards, MS Teams training, and a need for physical presence in the office or for service automation. All sectors were requested to submit their needs and requirements in order for the MOE higher management to evaluate and supply them. As these requirements were then gradually addressed, percentages across most sectors increased, as illustrated in Figure 4 below.

As can be seen from the bar graph, the Curriculum and Assessment Sector along with the School Operations Sector percentages were the same before and after supplying the needs. This can be referred to the dynamic infrastructure and automated services these two sectors continuously demonstrate. On the other hand, Performance Improvement Sector readiness increased significantly from $61 \%$ to $89 \%$ after receiving the needed supplements. The same applies to the Sector of Accreditation which shows a big rise in its readiness to work remotely. Most probably, the nature of work in these sectors did not require a dynamic infrastructure before the pandemic; therefore, the change after being supplied with their needs had become evident in their readiness for working remotely.

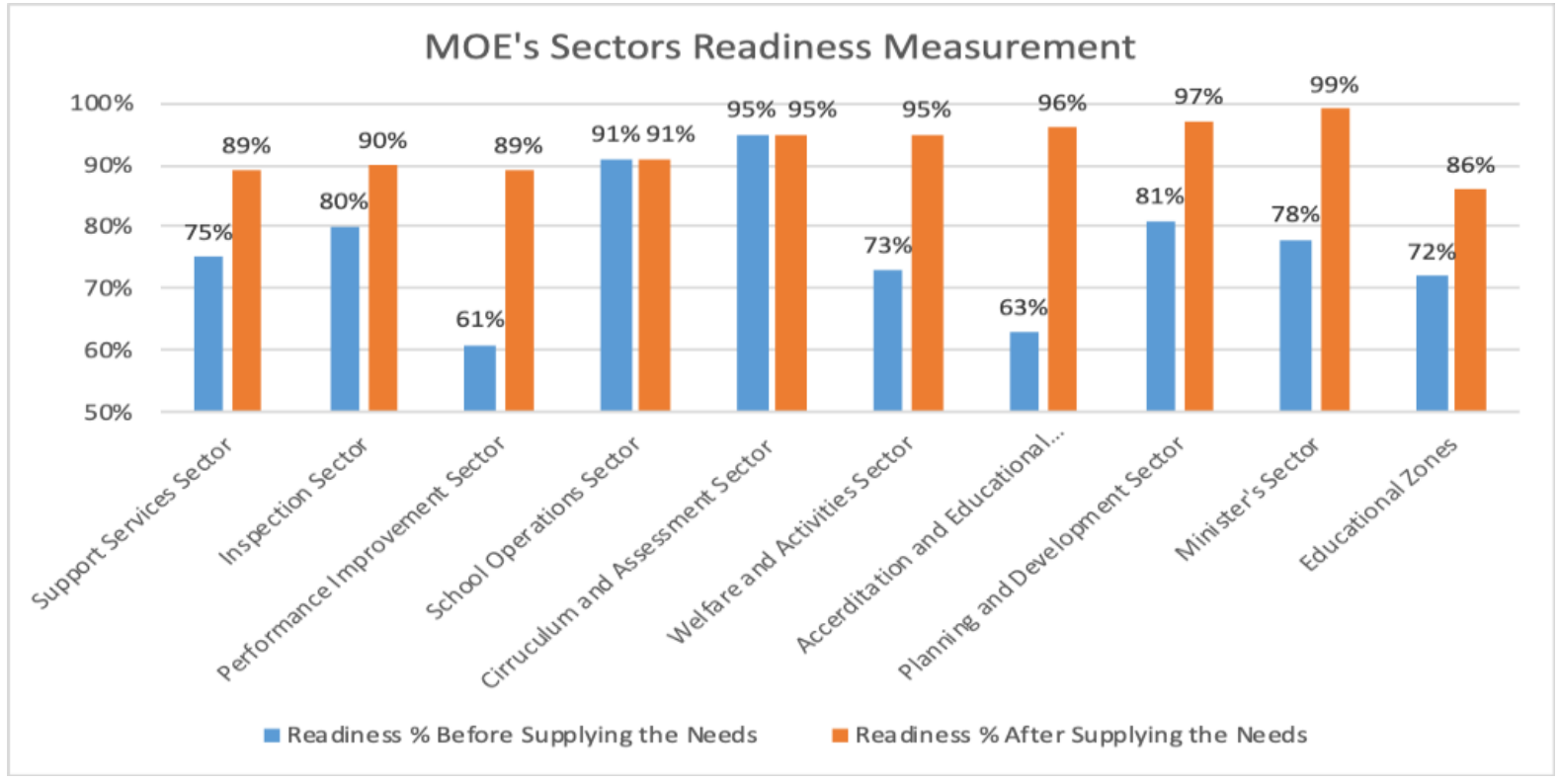

Figure 4: MOE's sectors readiness measurement

\subsection{Information Technology Department Readiness}

The Information Technology (IT) department was selected for this study due to their vital role in supporting other MOE departments through promptly addressing their technical needs. They were able to grant employees full remote access to systems usually used in an office environment as well as to 
shared folders. They also assisted other departments in transferring office calls to a computer application and facilitated the process of employees relocating their office desktop computers at home. Besides, the department worked on the implementation of cloud-based setup for all platforms, and the expansion of IT infrastructure capacity to accommodate all MOE employees working remotely and all students on elearning platforms.

The department customer services were also able to establish fully automated e-services with all electronic verification, signatures, and delivery. They have successfully closed around 12,000 technical report tickets submitted since the beginning of the e-learning/remote working experience. The IT department have remotely trained employees from different departments including Human Resources, Customer Happiness Centers, and School Operations in order to provide them with guidance on provision of technical support during their interactions with teachers and students (Figure 5).

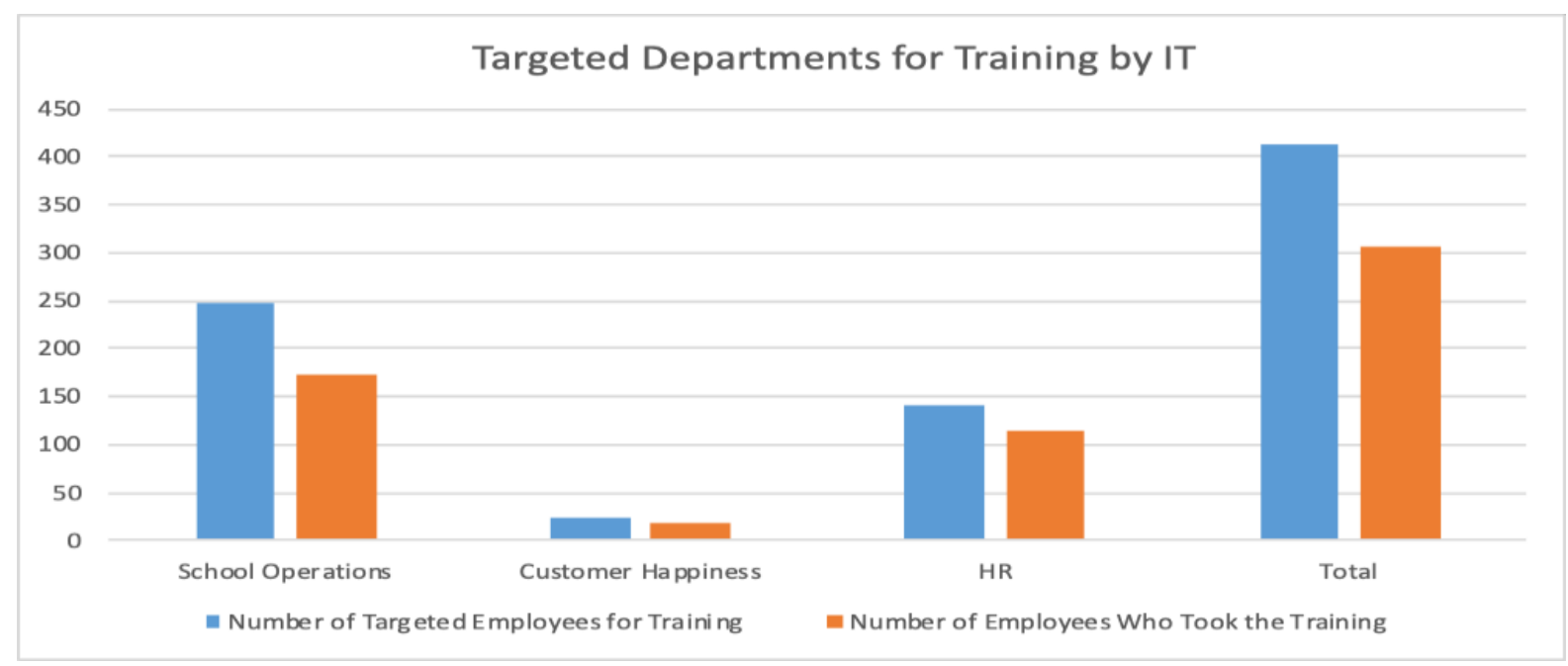

Figure 5: Targeted departments for training by IT

\section{2. $\quad$ Strategy and Future Department Readiness}

The Strategy and Future department was selected for this study due to the significant role they have played in evaluating and expediting the remote working process for the entire ministry through their aforementioned initiative, the Business Continuity Project. Their readiness for the transition was facilitated by their prior exposure to MS Teams and MS Planner before this crisis. All departmental employees were able to work from home on dedicated individual laptops. Their most significant challenge was the issue of remote access to their projects system and shared folder which was eventually resolved by the MOE IT team.

The department has demonstrated increased levels of productivity since the activation of remote working in March 2020 compared to previous months, rising from $93.5 \%$ at the beginning of the year to reach $100 \%$ by the end of March. Table 1 below shows details of task completion and productivity levels as per each section in this department. 
Table 1: Productivity levels as per strategy and future department's sections

\begin{tabular}{|c|c|c|c|c|c|c|c|c|c|}
\hline \multirow[t]{2}{*}{ Section } & \multicolumn{3}{|c|}{ Jan 2020} & \multicolumn{3}{|c|}{ Feb 2020} & \multicolumn{3}{|c|}{ Mar 2020} \\
\hline & $\begin{array}{l}\text { No. } \\
\text { Tasks }\end{array}$ & Achieved & $\begin{array}{c}\text { Achiev } \\
\text { ement } \\
\%\end{array}$ & $\begin{array}{l}\text { No. } \\
\text { Tasks }\end{array}$ & Achieved & $\begin{array}{c}\text { Achiev } \\
\text { ement } \\
\%\end{array}$ & $\begin{array}{l}\text { No. } \\
\text { Tasks }\end{array}$ & Achieved & $\begin{array}{c}\text { Achieve } \\
\text { ment } \%\end{array}$ \\
\hline $\begin{array}{l}\text { Strategy } \\
\text { Section }\end{array}$ & 13 & 13 & $100 \%$ & 12 & 11 & $91.67 \%$ & 13 & 13 & $100 \%$ \\
\hline $\begin{array}{l}\text { Performance } \\
\text { Section }\end{array}$ & 13 & 12 & $92.31 \%$ & 17 & 16 & $94.12 \%$ & 26 & 26 & $100 \%$ \\
\hline $\begin{array}{l}\text { Operations } \\
\text { Section }\end{array}$ & 16 & 16 & $100 \%$ & 20 & 19 & $95 \%$ & 32 & 32 & $100 \%$ \\
\hline $\begin{array}{l}\text { Excellence } \\
\text { Section }\end{array}$ & 8 & 8 & $100 \%$ & 15 & 14 & $93.33 \%$ & 21 & 21 & $100 \%$ \\
\hline
\end{tabular}

The department offered 44 existing e-services, to which 37 additional ones were added following the outbreak of the crisis. A breakdown of the services is shown in Table 2 below.

Table 2: Number of services overseen by strategy and future department

\begin{tabular}{lcc}
\hline \multicolumn{1}{c}{ Type of Service } & $\begin{array}{c}\text { Month } \\
\text { Feb/2020 }\end{array}$ & $\begin{array}{c}\text { Month } \\
\text { April/2020 }\end{array}$ \\
\hline Total Services (Subsidiary\Supplementary) & 91 & 91 \\
Priority Services & 10 & 10 \\
Total Services & 101 & 101 \\
Electronic Services (E-services) & 44 & 81 \\
Non-transferable Services & 5 & 5 \\
\hline
\end{tabular}

\section{3. $\quad$ Training and Career Development Department Readiness}

The Training and Career Development department was selected for this study due to their crucial role in ensuring that teachers and education professionals are appropriately trained for the e-learning experience, and that other MOE employees are similarly trained for the transition into remote working.

The department initiated an online training program for teachers at public and private schools in early March 2020. Teachers who attended this training reported a satisfaction rate of 4.31 out of 5 . The numerical rate of technical issues reported by teachers during the training, however, was 3.51 out of 5 , which evidenced the need for the department to apply continuous improvement initiatives to the training platforms. In the case of school leadership, the Training and Career Development department successfully conducted training on "Leading E-learning". Figure 6 below summarizes the number of teachers and leadership team members who attended the training from both sectors. It should be noted that the department also activated a live streaming platform to raise awareness of the importance of elearning, which has reached 6,750 views. 


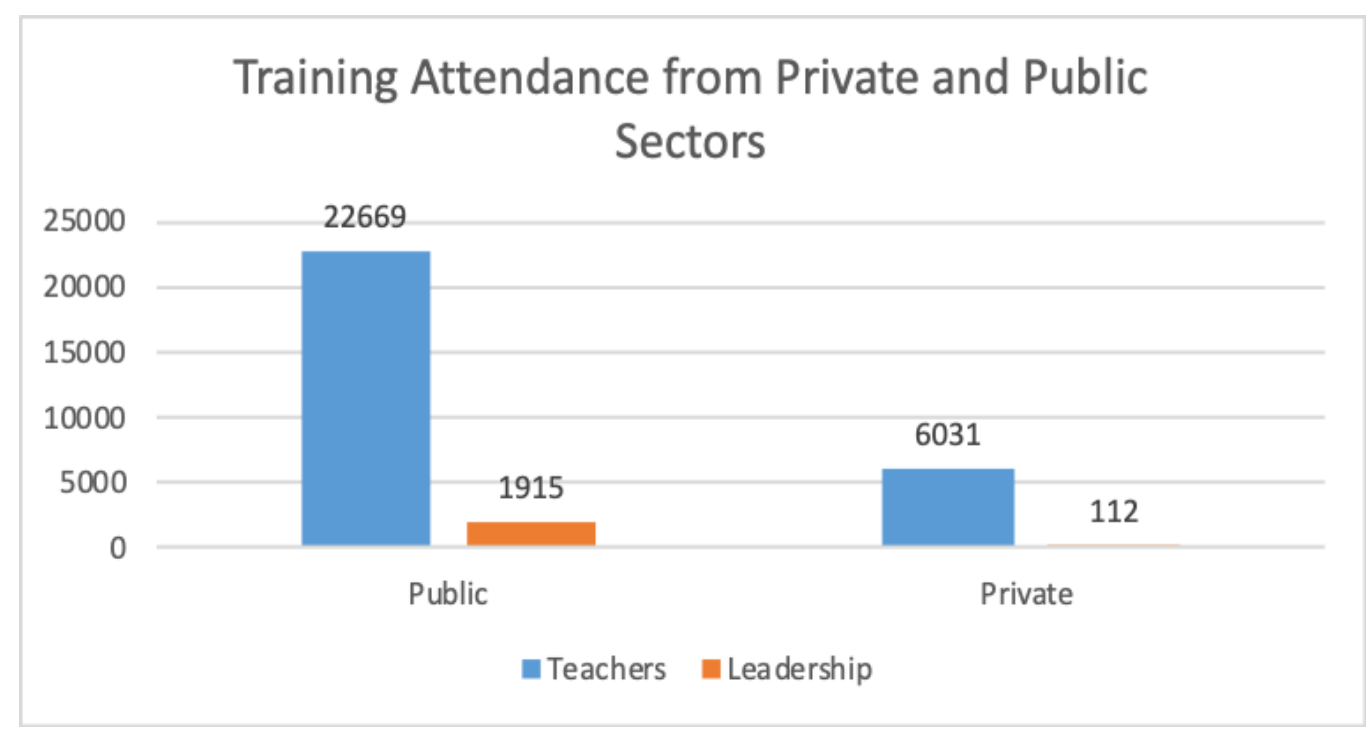

Figure 6: Training attendance from private and public sectors

\subsection{Scholarships Department Readiness}

The Scholarships department was selected for this study due to their position as the primary link between the country and those students studying abroad. At the commencement of the crisis, the department divided its employees according to the $\mathrm{ABC}$ work model until such time as they were fully functional from home. Their focus was on immediate contact with students studying abroad, tracing their locations, and facilitating their return to the UAE in coordination with the relevant authorities.

The department shared electronic forms with students in order to document details of their scholarships and in the case of any not willing to return to the UAE, their reasons. Around 880 out of 1,130 respondents have completed this form, with the remaining 250 still in the process of direct contact or of deciding on their status.

Communication with students abroad was conducted via SMS, emails, and Telegram groups to provide guidance on procedures for returning home, or support and precautions in the case of any having valid reasons to remain in their host country. With the support of the MOE IT department, the Scholarships department also succeeded in transferring all incoming and outgoing office calls to a computer application.

The department also collaborated with the Academic Counseling department to answer concerns and questions relating to scholarships admission for the upcoming academic year, after they had trained counselors in the process of addressing scholarship-related inquiries. In order to reply to students in a timely manner, employees were divided into groups to accommodate time differences between the UAE and different host countries.

\subsection{Organizational Directorate and Educational International Relations Department Readiness}

The Organizational Directorate and Educational International Relations was selected due to their important role in interacting with international educational institutions and organizations outside the UAE. During the transition period to remote working, the department gathered information from UAE embassies and consulates across the world and initiated discussions and direct meetings between the UAE Minister of Education and his counterparts in other countries. They obtained valuable information 
regarding health precautions and status in different educational institutes; actions and decisions taken in these institutions pertaining to the continuation or disruption of work/education; and information on the emotional or physical impacts on students and parents. They have submitted reports on all these areas in order to allow UAE leadership to develop plans based on full awareness and best practices.

\subsection{Institutional Licensing Department Readiness}

The Institutional Licensing department was selected for this study due to their significant role in the interaction with educational institutions in the UAE. The department also had some prior experience in communicating with clients via online services prior to the transition to remote working.

In collaboration with NCEMA, the department circulated a list of rules to all educational institutions detailing the management of critical conditions of the pandemic. Firstly, all institutions were requested to implement disinfections/sterilization programs. The need for learning to be shifted onto e-platforms was then communicated. Students returning from abroad were directed to follow quarantine rules imposed by the Ministry of Health.

The department shared an electronic form with all institutions, requiring them to report their readiness for e-learning, and also circulated a survey enabling students to evaluate the readiness of their institutions. Following this, they were able to compare results from both the form in order to accurately determine the readiness of each individual institution.

Under the auspices of the Institutional Licensing department, the ministry held its first virtual forum in early April 2020, where more than 100 leaders of differing Higher Education Institutes (HEIs) were able to discuss best practices in managing the impact of Coronavirus on the higher education sector. Participating HIEs included Khalifa University, UAE University, Zayed University, the American University of Sharjah, Hamdan Bin Mohammed Smart University, and the Higher Colleges of Technology. Each of these institutions shared their experiences and practices in e-learning, the challenges they had faced and how had been able to overcome them. Table 3 and Figure 7 summarize details from the forum attendance and the categories of questions and discussions raised by the participating higher education institutions.

Table 3: The educational forum attendance details

\begin{tabular}{l} 
Virtual Educational Forum for UAE \\
Higher Education Institutes - April \\
2020 \\
\hline $\begin{array}{c}\text { Total Attendees } \\
\text { Questions }\end{array}$ \\
Unique Conversations \\
\\
Total Attendees \\
\end{tabular}




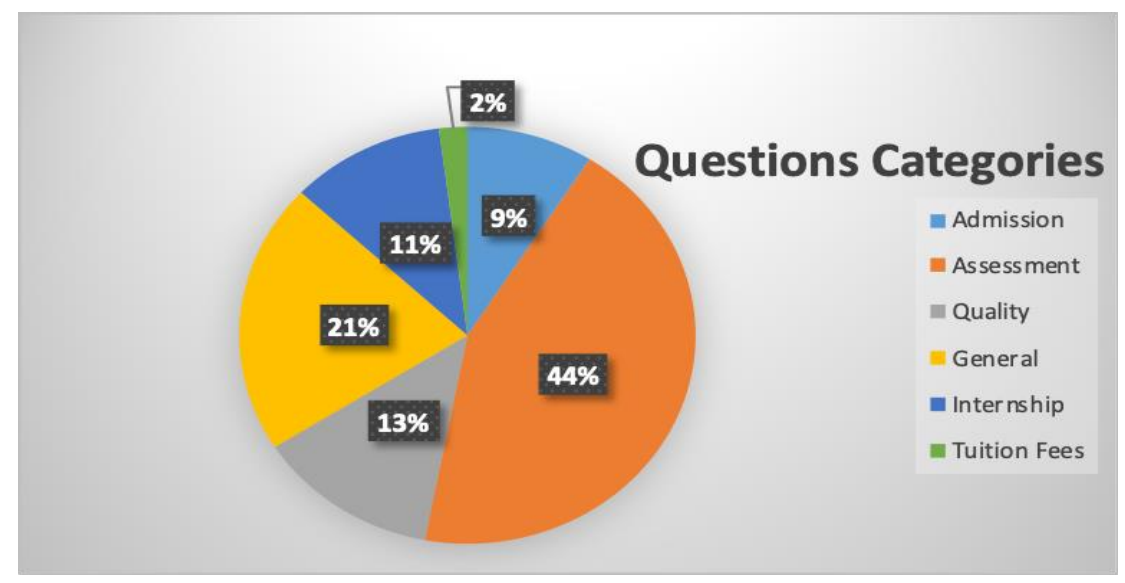

Figure 7: Categories of questions at the educational forum

\section{Conclusions}

\subsection{Challenges of Introducing Remote Work and the Opportunities Created}

Any changes in an environment, system, or process can impose challenges which might require reevaluation or readjustments. It was emphasized by MOE leadership that any such challenges accompanying this experience should ideally be transformed into advantages and utilized as a learning curve.

One of these challenges was the inevitable disruption caused to long-standing practices in the presentation of a sudden and unanticipated risk. Such disruption might entail the need for rapid decisionmaking and potentially inefficient solutions, as well as having financial and other consequences. Disruption has also occurred to pre-existing plans including events, conferences, exhibitions, international and national test arrangements. Some of these were instead held virtually, but others were of necessity delayed or cancelled completely, resulting in significant relevant endured costs.

Moreover, as the MOE is a service provider with numerous clients, an additional challenge was the continuation of services whilst responding to many client inquiries. Imposing new technical solutions or new online systems for employees is likely to raise significant questions from users, particularly those from widely different age groups and technical backgrounds. Adapting to these new systems inevitably requires additional support and training.

Many of these challenges have been transformed from obstacles into advantages and opportunities for learning and growth. Disruption to existing plans has imposed the requirement of technological solutions on platforms accommodating large-scale events and testing. The National and International Examinations department has faced a disruption in its Emirates SAT (EmSAT) test administration which is normally conducted for Grade 12 students on a yearly basis; the Professional Licensing department has faced similar disruption to the licensure tests that they conduct for teachers and education professionals. Consequently, both departments are currently exploring solutions towards resuming the administration of these tests, using online reliable online platforms with all testing procedures adjusted accordingly and in coordination with the IT department.

Furthermore, the need for service continuation has expedited the process of transforming services into full electronic mode. The increase in client inquiry numbers has led to the establishment and training of a volunteer team which now assists in internal and external responses, solves problems, and spreads awareness. This volunteer team can be called upon during any period of need in preference to the hiring of large numbers of new employees. In addition, repeated virtual training exposed large numbers of trainees to a new method of learning development. Prior to this, MOE training was normally conducted 
in dedicated training centers or venues. The advent of online training has facilitated a focus on specific groups with urgent or particular needs, as well as expediting the collection of prompt feedback and the enhancement of the overall experience.

Overall, the adoption of remote working practices at the ministry has demonstrated significant advantages in and of itself during these critical times: such a shift away from the traditional long-term existing work model would otherwise likely have taken an appreciably longer period of time. This shift and the commensurate advantages experienced along with it has succeeded in establishing policies that place remote working as a valid work model to be adopted in the coming years. This itself has significant future potential for a reduction in financials by lowering operational costs of space utilization, rent, commute, and time. Besides, this transition has expedited the testing and usage of existing developed platforms invested in by the ministry, such as learning by distance for students, virtual training, virtual libraries, and other electronic services.

Although the COVID-19 pandemic has increased physical distancing, it has simultaneously encouraged open dialogues with both local and international stakeholders to discuss the mitigation of challenges, review best practices, and implement solutions based on the current and future needs of the country.

\subsection{Working Remotely as an Option in the Future of Business}

This paper highlighted the efforts of the UAE leadership to ensure the continuity of education across the country, and to demonstrate that irrespective of any obstacle, the learning of every student in the UAE remains the highest priority. As a response to the COVID-19 pandemic and with the support of UAE leadership, the Ministry of Education, as one of the country's leading entities, has adopted remote working for employees as well as e-learning through virtual environments. The Ministry of Education serves the community by providing benefits to different stakeholders including educational institutions, teachers and education professionals, trainers and trainees, students, and parents. Hence, the originality of this research stems from the fact that the remote working practices adopted by MOE do not only affect its departments and employees but the whole community as well, which is implicitly our point of interest in this paper.

The study attempted to evaluate the experience of remote working at the ministry by assessing its readiness factor. Interviews were conducted with several departments to get their feedback and study their measurements. One of the important findings here is the relatively high percentage of readiness MOE departments had demonstrated at the early stages of the pandemic (75\%) as well as the support provided by the business continuity team to raise the readiness of the remaining $25 \%$ of departments. Another highlight in this paper is the vital role of the Information Technology (IT) department in supporting other MOE departments through promptly addressing their technical needs. Besides, the implementation of cloud-based setup for all platforms and the expansion of IT infrastructure capacities have tremendously facilitated e-learning for students in general and higher education.

Being keen on conducting this study in line with the incident of COVID-19 outbreak has imposed a restriction over the time period for gathering and analyzing data, which could be considered a limitation to this study. Considering departments of the Ministry of Education only with no reference to other ministries and federal entities in the country could be a limitation as well. However, this paper provides insights into the activation of remote working when needed and discusses how in many cases, obstacles were able to be turned into opportunities. Remote working might in fact be considered as a future option due to the significant advantages and outcomes that have been captured during this period and highlighted in this paper. 
It is recommended in future studies to enlarge the scale and sample size of interviewee departments representing every sector at the Ministry of Education. In addition, the enlargement of scale could expand this (or any similar) study across all ministries and federal entities in the UAE. This is admittedly an optimistic perspective, but nevertheless an achievable one should teams representing each participating entity be able to collaborate under the supervision and guidance of a suitable research institution.

\section{Acknowledgements}

The authors of this paper would like to acknowledge the tremendous efforts of the internal teams of the Ministry of Education and the support of the management in facilitating the transition and enabling their employees and granting approval to share the overall experience.

\section{References}

Bailey, D., \& Kurland, N. (2002). A Review of Telework Research: Findings, New Directions, and Lessons for the Study of Modern Work. Journal of Organizational Behavior, 383-400.

Baker, E., Avery, G., \& Crawford, J. (2006). Home Alone: The Role of Technology in Telecommuting. Information Resources Management Journal, 19, 1-22.

Bartsch, S., Weber, E., Buttgen, M., \& Huber, A. (2020). Leadership matters in crisis-induced digital transformation: how to lead service employees effectively during the COVID-19 pandemic. Journal of Service Management, 32(1), 71-85.

Bishop, A., Riopelle, K., Gluesing, J., Danowski, J., \& Eaton, T. (2010). Managing Global Compliance through Collaborative Innovation Networks. Procedia Social and Behavioral Sciences 2, 64666474 .

Boulin, J.-Y. (2016). Working time in the new social and economic context. Transfer 2(1), 197-211.

Clark, E. (1998). Telecommuting and Working from Home. A Contemporary Renaissance: Changing the Way We Communicate, 21-25.

Dangmei, J. (2016). Building Trust in A Virtual Team: A Conceptual Framework. International Journal of Management and Social Science Research Review, 1(29), 30-35.

Elshaiekh, N. E., Hassan, Y., \& Abdallah, A. (2018). The Impacts of Remote working on Workers Performance. Procedia International Arab Conference on Information Technology (ACIT), 1-5.

Federal Authority for Government Human Recources. (2020). Retrieved from https://www.fahr.gov.ae/en/news/15/3/2020/distance-working.aspx

Felstead, A., \& Henseke, G. (2018). Assessing the growth of remote working and its consequences for effort, well- being and work- life balance. New Technology, Work and Employment, 1-18.

Iscan, O., \& Naktiyok, A. (2005). Attitudes towards telecommuting: the Turkish case. Journal of Information Technology, 52-63.

Kumar, P. (2014). Information Technology: Roles, Advantages and Disadvantages. International Journal of Advanced Research in Computer Science and Software Engineering, 4(6), 1020-1024.

Liao, C. (2017). Leadership in virtual teams: A multilevel perspective. Human Resource Management Review, 27(4), 648-659. 
Lukić, J., \& Vračar, M. (2018). Building and Nurturing Trust Among Members in Virtual Project Teams. Strategic Management, 23(3), 10-16.

Mehtab, K., Rehman, A., Ishfaq, S., \& Jamil, R. (2017, July). Virtual Leadership: A Review Paper. Mediterranean Journal of Social Sciences, 8, 183-193.

Mertens, W., \& Recker, J. (2020). How store managers can empower their teams to engage in constructive deviance: Theory development through a multiple case study. Journal of Retailing and Consumer Services, 52.

Ministry of Education in the United Arab Emirates. (n.d.). Retrieved April 2020, from https://www.moe.gov.ae/Ar/AboutTheMinistry/Pages/OrgChart.aspx

Oliver, Z., Schoewe, D., \& Lawrence, S. (2016). Attracting Talent Who Can Live and Work Anywhere. RTI International, 1-19.

Olson, M. (1983). Remote Office Work: Changing Work Patterns in Space and Time. Communications of the ACM, 26, 182-187.

Pierce, R., \& Amant, K. (2011). Working from home in a globally distributed environment. In Proceedings of the 29th ACM international conference on Design of communication (pp. 223-226).

United Arab Emirates Ministry of Human Resources and Emiratisation. (2020). Retrieved from https://www.mohre.gov.ae/en/media-centre/news/15/3/2020/mohre-urges-private-establishmentsto-take-precautions-to-protect-workers-from-coronavirus.aspx

United Arab Emirates Ministry of Interior. (2020). Retrieved from https://www.moi.gov.ae/en/media.center/News/040101.aspx

United Arab Emirates Telecommunication Regulatory Authority. (n.d.). Retrieved April 2020, from https://www.tra.gov.ae/en/about-tra/tra-initiatives-in-response-to-covid-19.aspx

United Arab Emirates Vision 2021. (n.d.). Retrieved April 2020, from https://www.vision2021.ae/en

Valenduc, G., \& Vendramin, P. (n.d.). ICT, flexible working and quality of life. 1-6.

Wang, B., Liu, Y., Quan, J., \& Parker, S. K. (2021). Achieving effective remote working during the COVID-19 pandemic: A work design perspective. Applied Psychology, 16-59.

Weinbaum, C., Triezenberg, B., Mezo, E., \& Luckey, D. (2018). Understanding Government Telework. RAND Corporation Santa Monica United States.

Wiley Online Library. (2005). Retrieved from https://onlinelibrary.wiley.com/doi/epdf/10.1002/job.356

World Health Organization. (2020). Retrieved April 2020, from https://www.who.int/healthtopics/coronavirus\#tab=tab_1 


\title{
Bekerja dari Jarak Jauh Selama Pandemi COVID-19: Upaya Kementerian Pendidikan di Uni
}

\author{
Emirat Arab
}

\begin{abstract}
Abstrak
Menyusul wabah global pandemi COVID-19, semua pekerjaan tidak lagi dilakukan dengan cara tradisional. Hal ini telah menciptakan tekanan pada bisnis untuk beralih ke mode kerja jarak jauh untuk menghindari gangguan yang parah. Uni Emirat Arab (UEA) telah berusaha untuk menghadapi tantangan yang menyertai krisis ini dan mencari solusi dengan visi yang bijaksana dan dukungan terus-menerus dari kepemimpinannya. artikel ini membahas transisi prosedur kerja di salah satu entitas paling berpengaruh di UEA; Kementerian Pendidikan (MOE). Tujuannya di sini adalah untuk menjelaskan bagaimana hambatan telah diubah menjadi peluang agar karyawan KDR untuk terus bekerja dari jarak jauh selama kondisi kritis tersebut. Ini diilustrasikan oleh upaya departemen kementerian yang diwawancarai untuk umpan balik mereka selama studi. Studi ini memberikan wawasan tentang aktivasi pekerjaan jarak jauh dalam menanggapi insiden mendadak dengan menyoroti pengukuran dan faktor yang berkontribusi pada kesiapan entitas untuk transisi semacam itu. Studi ini menganalisis nilai dan orisinalitas praktik kerja jarak jauh dan dampaknya terhadap masyarakat luas
\end{abstract}

Kata kunci: bekerja dari jarak jauh, telework, kerja jarak jauh, lingkungan virtual, COVID 19 